\section{Biosafety measures adopted by nursing undergraduates in daily activities in spaces of laboratory practices}

\section{Medidas de biossegurança adotadas por graduandos em enfermagem no cotidiano dos espaços de práticas laboratoriais}

\section{Medidas de bioseguridad adoptadas por estudiantes universitarios de enfermería en espacios de práctica diaria de laboratorio}

Ivonizete Pires Ribeiro ${ }^{1}$, Elizana Carvalho Oliveira ${ }^{1}$, Jessyca Samara de Sampaio Silva ${ }^{1}$, Herica Emília Félix de Carvalho ${ }^{2}$

\footnotetext{
${ }^{1}$ University Center UNINOVAFAPI, Nursing Department, Teresina, Piauí, Brazil.

${ }^{2}$ College of Nursing of Ribeirão Preto, University of São Paulo, Nursing Department, Ribeirão Preto, São Paulo, Brazil.
}

\begin{abstract}
Objective: to analyze the biosafety measures adopted by nursing undergraduates in daily activities in spaces of laboratory practices. Method: descriptive, qualitative analysis study performed at a Higher Education Institution in the period from April to June 2018, with 30 students. For the analyses of interviews, Collective Subject Discourse was utilized. Results: as for Personal Protective Equipment (PPE) usage, 24\% used gloves, followed by white coat and mask, with $19 \%$ and $18 \%$ each, respectively. Referring to moments of Hand Hygiene $(\mathrm{HH})$ during the laboratory practices, $32 \%$ performed the hygiene before and $26 \%$ after the practice. It is observed that the scholars' knowledge about biosafety is broad but limited to PPE usage. Conclusion: it is verified that the use of biosafety measures in this environment is still a challenge, for it be limited to PPE and HH usage.
\end{abstract}

Descriptors: Containment of Biohazards; Occupational Risks; Health Education; Occupational Health Nursing.

\section{RESUMO}

Objetivo: analisar as medidas de biossegurança adotadas por graduandos em enfermagem no cotidiano dos espaços de práticas laboratoriais. Método: estudo descritivo, de análise qualitativa realizado em uma Instituição de Ensino Superior no período de abril a junho de 2018, com 30 estudantes. Para as análises das entrevistas utilizou-se o Discurso do Sujeito Coletivo. Resultados: quanto ao uso de Equipamentos de Proteção Individual (EPI), 24\% usaram luvas, seguido do jaleco e máscara, com $19 \%$ e $18 \%$ cada, respectivamente. No que se refere aos momentos de Higienização das Mãos (HM) durante as práticas laboratoriais, 32\% realizam a higiene antes e $26 \%$ após a prática. Observa-se que o conhecimento dos acadêmicos sobre biossegurança é amplo, mas limitado ao uso do EPI. Conclusão: verifica-se que o uso de medidas de biossegurança nesse ambiente ainda é um desafio, por ser limitado ao uso de EPI e HM. Descritores: Contenção de Riscos Biológicos; Risco Ocupacional; Educação em Saúde; Enfermagem do Trabalho.

\section{RESUMÉN}

Objetivo: analizar las medidas de bioseguridad adoptadas por los estudiantes de enfermería en la práctica diaria de los espacios de laboratorio. Método: estudio descriptivo de análisis cualitativo realizado en una institución de educación superior de abril a junio de 2018, con 30 estudiantes. Para el análisis de las entrevistas utilizamos el Discurso del sujeto colectivo. Resultados: Con respecto al uso de Equipo de Protección Personal (EPP), el 24\% usaban guantes, seguido de la delantal de laboratorio y la máscara, con $19 \%$ y $18 \%$ cada uno, respectivamente. En cuanto a los momentos de Higiene de Manos (HM) durante las prácticas de laboratorio, el 32\% realiza higiene antes y el $26 \%$ después de la práctica. Se observa que el conocimiento de los estudiantes de bioseguridad es amplio, pero limitado al uso de EPP. Conclusión: el uso de medidas de bioseguridad en este entorno sigue siendo un desafío, ya que se limita al uso de EPP y HM.

Descriptores: Contención de Riesgos Biológicos; Riesgos Laborales; Educación en Salud; Enfermería del Trabajo.

\section{How to cite:}

Ribeiro IP, Oliveira EC, Silva JSS, Carvalho HEF. Biosafety measures adopted by nursing undergraduates in daily activities in spaces of laboratory practices. Rev Pre Infec e Saúde [Internet]. 2019;5:9309. Available from: http://www.ojs.ufpi.br/index.php/nupcis/article/view/9309 DOI: https://doi.org/10.26694/repis.v5i0.9309

Rev Pre Infec e Saúde. 2019;5:9309 


\section{INTRODUCTION}

Biosafety relates to a set of measures aimed at preventing, minimizing or eliminating inherent risks concerning activities of research, education, production, provision of service and technological development. These measures have as objective promotion of human, animal health, preservation of environment and quality of results. ${ }^{1}$

With respect to the biosafety measures in laboratory practices in health education, it is very important to highlight its relevance for health professionals and, mainly, during professional development process. Practical activities in laboratories are part of everyday life of undergraduates in health, and the biosafety knowledge is essential because the handling of materials as well as the performed procedures may endanger the individual, collective, environment and all who walk in laboratory. ${ }^{2}$

When considering the work routine in health facilities, professional development, mainly from nursing, demands that the professional be aware to biosafety measures to ensure the protection of his health. Therefore, the biosafety education is necessary to professionals since their development, preparing them for professional life by means of disciplines that approach the subject and instructing them about biosafety standards in laboratory and practical classes. Thus, the professionals will be sufficiently prepared and safe to walk into any health facility and develop their activities. ${ }^{3}$

It is worth noting that studies involving accidents occasioned in research laboratories and health services are still incipient, but there are already important attitudes related to the theme. ${ }^{4}$ In this sense, the emerging discussion about biosafety measures adopted by nursing undergraduates in daily activities in spaces of laboratory practices is necessary to know undergraduates adherence to biosafety standards, their knowledge about biosafety, Personal Protective Equipment (PPE) and Collective (CPE) usage and their ease and difficulty in utilizing this equipment.

Therefore, it was chosen as objective to analyze the biosafety measures adopted by nursing undergraduates in daily activities in spaces of laboratory practices.

\section{METHOD}

It is a descriptive study performed at a Higher Education Institution (HEI), private, located in city of Teresina, state of Piauí, Brazil. The study period was from April to June 2018.

Scholars from undergraduate nursing course who were attending practical subjects, that is, those who were properly enrolled and attending $2 \mathrm{nd}$, 3rd, 4th and 5th grade participate in the study. The sample was intentional, firstly the invite for study participation was performed on each one of the grades mentioned above and, later, interviews were scheduled in private place.

The interviews were previously scheduled and performed at private clinic after participants' consent by signing Informed Consent (IC), on the premises of the selected institution, according to participants' availability. The interviews were approximately 15 minutes long each. The interview technique was guided by a semistructured script composed by two parts: sociodemographic data and four questions about practices with safety based on manuals about biosafety from Ministry of Health ${ }^{5}$ and regulatory 
Ribeiro IP, et al.

standards $6^{6}$ and $32^{7}$ (What do you understand about biosafety? Which Personal Protective Equipment (PPE) you utilize in your laboratory practices? What difficulties do you have in using PPE? In which moments of laboratory practices the hand hygiene is performed?).

For quantitative data analysis, descriptive statistics were utilized, and for qualitative data analysis, Collective Subject Discourse (CSD) was utilized. In this study, the CSD results were presented in two thematic categories followed by their respective Central Ideas $(\mathrm{Cl})$, sequenced by selected samples of verbal material of individual testimonies that better described their contents and the discussion. ${ }^{8-9}$

The present study follows all the ethical and legal aspects of Resolution 466/12 of National
Biosafety measures in spaces of practices

Health Council, and was approved by the Research Ethics Committee of the Centro Universitário UNINOVAFAPI on February 14, 2019 with Opinion No. 3,147,766

\section{RESULTS}

Thirty nursing students from third, fourth and fifth grade participate in the study. Most of the students were female, with an average age of 20 years.

As for the Personal Protective Equipment (PPE) usage by nursing students in laboratory practices, most of them use gloves, followed by white coat and mask, respectively, with the highest percentages according to Figure 1.

Figure 1: Personal protective equipment usage by nursing students in laboratory practices.

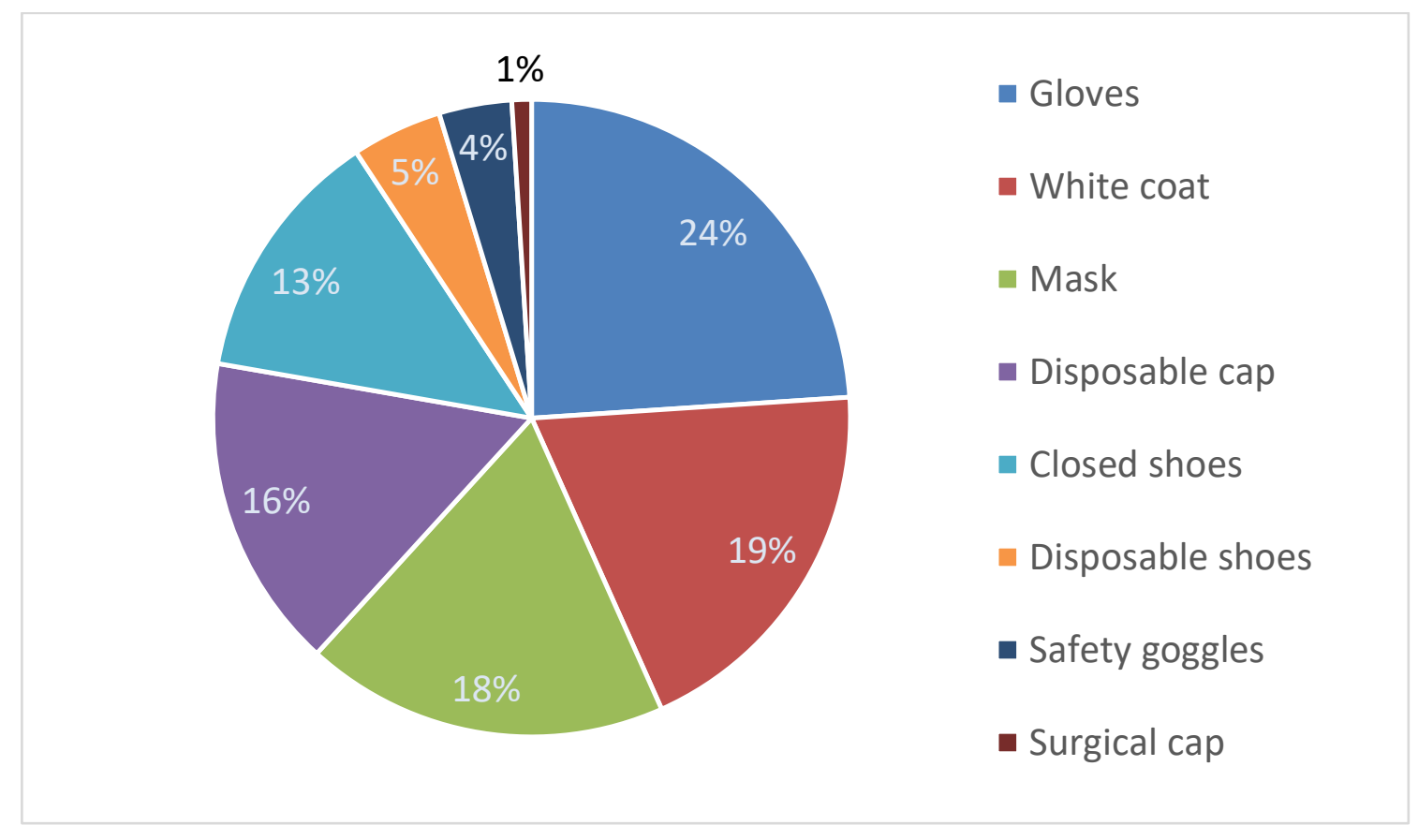

Regarding the hand hygiene moments performed by students during laboratory practices, it occurs most often before and after practice (Figure 2). 
Figure 2: Hand hygiene moments during laboratory practices.

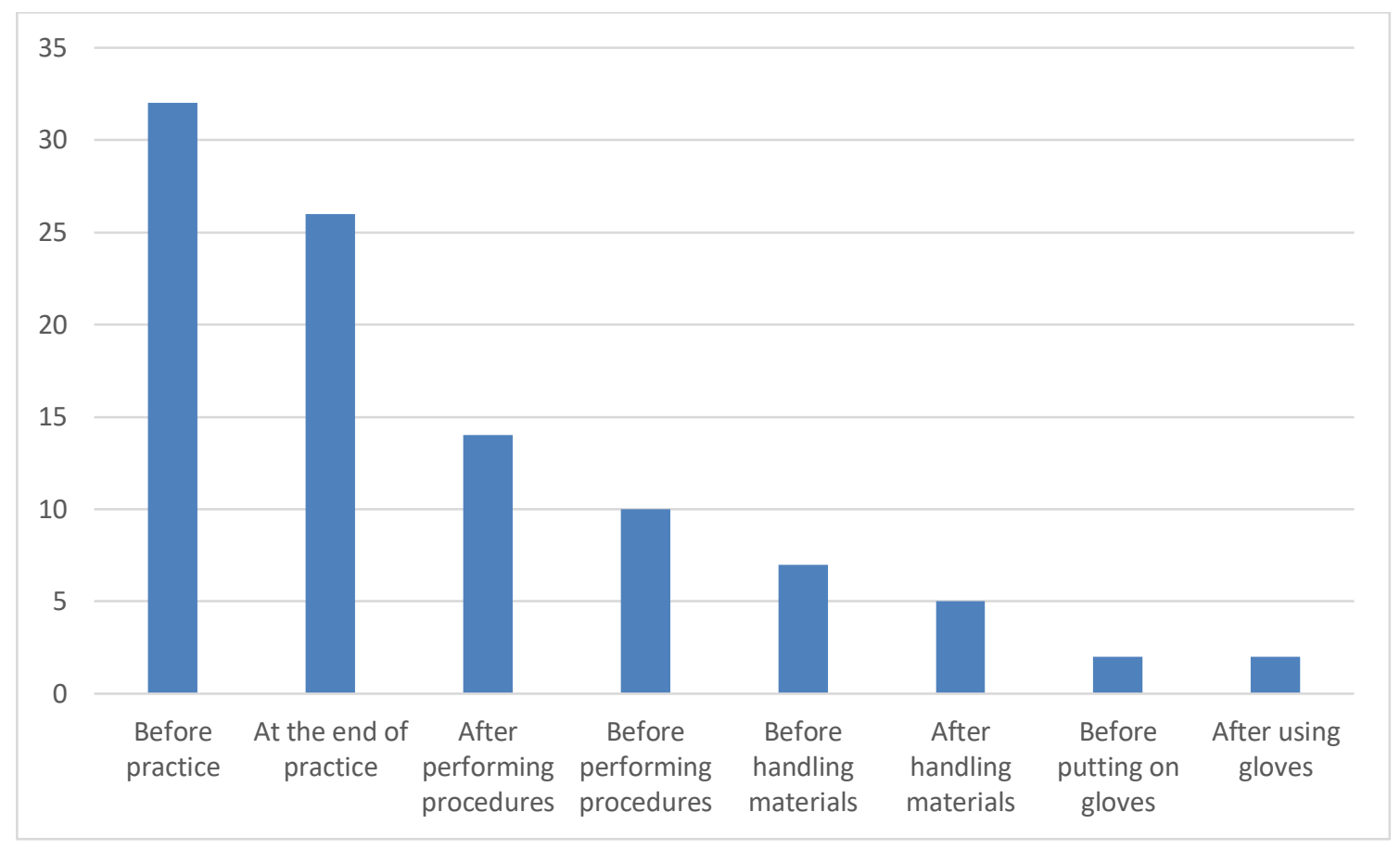

From the analyses of interviews, Collective Subject Discourses were built, divided in two central ideas, with their respective key words. The central ideas were: knowledge about biosafety; and difficulties in utilizing PPE.

1st Central Idea (Cl): Knowledge about biosafety

Key expressions:

- Prevention;

- Preventing accidents;

- Self-protection;

- Personal Protective Equipment;

- Technical standards;

- Risk minimization.

\section{Collective Subject Discourse}

Biosafety is a form of prevention, performed in laboratory, for preventing accidents. It is our self-protection. It is a set of actions aimed at professional and patient protection against diseases and microorganisms, aimed at Rev Pre Infec e Saúde. 2019;5:9309 preventing accidents in work environment. One of these actions includes PPE usage that is the basic protection equipment. For example, the use of gloves in doing some procedure with some contamination risk. Biosafety also approaches technical standards for safety of work environment such as laboratories for risk minimization. Biosafety in health is important for our development as future professionals. (A1, A2, A3, A4, A5, A6, A7, A8, A9, A10, A11, A12, A13, A14, A15, A16, A17, A18, A19, A20, A21, A22, A23, A24, A25, A26, A27, A28, A29, A30).

2nd Central Idea $(\mathrm{Cl})$ : Difficulty in using personal protective equipment

Key expressions:

- PPE availability;

- Changing gloves;

- Putting on sterile gloves;

- Fatigue;

- Risks. 
Ribeiro IP, et al.

\section{Collective Subject Discourse}

Most times, there is no difficulty, and when it exists is in relation to PPE availability in the health institution, changing gloves, practice of putting on sterile gloves and fatigue in utilizing mask. PPE is often missing in the institution, and this makes the practice more difficult and exposes us to risks. The constant changing of sterile gloves refers to the high number of patients to be attended. The practice of putting on sterile gloves is associated with the own practice, then the more we practice, the less difficulties we will have. In some situations, there is fatigue due to mask usage, mainly, in prolonged use and in non-refrigerated environment. (A1, A2, A3, A4, A5, A6, A7, A8, A9, A10, A11, A12, A13, A14, A15, A16, A17, A18, A19, A20, A21, A22, A23, A24, A25, A26, A27, A28, A29, $A 30)$.

\section{DISCUSSION}

According to the demographic data of nursing students, it was verified that $96.67 \%$ of the students are female, which was already expected once females are still predominant in nursing, as other national ${ }^{10-11}$ and international ${ }^{12-13}$ studies about the profile of nursing undergraduate show us. Concerning age, a young profile is observed, with an average age of 20 years, corroborating with the literature. The young age group in undergraduate courses may be explained due to the Brazilian government incentive in higher education. ${ }^{11,10}$

As for Personal Protective Equipment (PPE) usage in laboratory practices reported by students, the present study evidenced that the most used ones are gloves, white coat and mask.
Biosafety measures in spaces of practices

In a study developed with nursing undergraduates from Paraíba, it was noticed that gloves (86.7\%), masks (80.6\%) and disposable caps (53.5\%) were the PPE that obtained the most adherence by nursing scholars. ${ }^{14}$ Study performed in Nigeria described that $100 \%$ of nursing scholars reported the importance of glove usage before executing an invasive procedure. ${ }^{15}$ In relation to the least used PPE, it was noticed that the usage of safety goggles and surgical cap presented only $4 \%$ and $1 \%$, respectively. Similar and contradictory data were found, the similarity was with relation to the usage of safety goggles because $8.8 \%$ of the students reported that they have never used them. ${ }^{15-16}$ The contradictory data concern the use of surgical cap because $84 \%$ of students claimed that they always utilize this PPE. ${ }^{16}$

It is noteworthy that, according to Regulatory Standard (NR) 6, ${ }^{6}$ PPE is every device or product used in an individual way for risk protection, its usage will depend on the professional's work environment. NR $32^{7}$ establishes safety and health guidelines for professionals who work in health facilities. These standards must be known by all health students, both in simulation environment and in practical environment, because they will lead the risk prevention and safety attitudes in the development of health practices.

Regarding the reality about the PPE usage, it is verified that the active adoption of biosafety measures in laboratory practices by nursing scholars still pose a challenge because nonadherence to some PPE continues to occur. The education institute support in providing PPE and the emphasis to biosafety discussion become, then, essential in the early years of 
Ribeiro IP, et al.

undergraduate course. Moreover, the professors must be more demanding with the students regarding the adoption of coherent and fundamental measures to ensure their own protection as well as the patient's safety.

Referring to Hand Hygiene $(\mathrm{HH})$, in this study the nursing scholars reported that the moments $\mathrm{HH}$ is most performed are before and after the laboratory practices. The literature acknowledges this measure as effective in prevention of Healthcare-associated Infections (HAl) because it reduces the transmission of pathogenic microorganisms parallelly to the increase of professionals' adherence to $\mathrm{HH}$ procedure. ${ }^{17}$ International study reports that $98 \%$ of nursing scholars claim that know when and how to perform the $\mathrm{HH}$ in patient care; believe that $\mathrm{HH}$ is effective in preventing the transmission of infections; and believe that the undergraduate nursing course highlights the $\mathrm{HH}$ importance when taking care of patients. ${ }^{18}$

According to the Brazilian Health Regulatory Agency (ANVISA), HH is preconized in five moments: before contacting with patient and performing clean/aseptic procedures and after contacting with patient, risk of exposure to body fluids and contacting with surfaces next to patient. ${ }^{5}$ As for $\mathrm{HH}$ importance, it is worth mentioning that nursing students and professionals are exposed to risk of acquiring infections by direct contact with patient and his environment. However, when the contact involves body fluids and potential contaminated regions, the adherence to $\mathrm{HH}$ increases, realizing the seeking after self-care by students and professionals. This practice prevents the cross-
Biosafety measures in spaces of practices contamination of microorganisms and the environment contamination. ${ }^{19}$

The non-performance of $\mathrm{HH}$ before contacting with patient or aseptic procedure is a risk to patients' safety because it leads to microorganism transmission in patient care environment, even more when the patient's vulnerability to infections is considered. ${ }^{20}$

Referring to scholars' knowledge about biosafety in health, the students summed it up in one word: "prevention". It is observed that the knowledge is broad but limited to PPE usage. This limitation may be associated with theme simplification in development of professional nurse, the lack of rigor by professors concerning the biosafety standards in practice places, from laboratory to supervised practice. The acquirement of knowledge about biosafety in health influences the scholars in concept construction, while the practice with the use of standards ease the attitude development by students, which is essential for reflection, knowledge construction and learning by pupil.

It should be noted that the students point out the biosafety in health as an important theme to be discussed in professional development, but to follow the biosafety standards, they need to adopt a prevention attitude, that depends on a learning process. Study performed with nursing undergraduates describes that the PPE education is, also, taught in simulation laboratory. ${ }^{21}$

The simulation is used for supplementing the didactic training, it can represent additional benefits in comparison with expositive class. The clinical setting is indispensable and for this, the student should go to clinical practice with all biosafety measures internalized to his practice, 
Ribeiro IP, et al.

and the lecture is given in a pure educational environment, does not include practical training and contributes with the continuous training outside classroom. ${ }^{18}$

Respecting the difficulties in utilizing PPE, the scholars reported that most of the time there is no difficulty and when there is any, it is related to the lack of PPE, changing gloves, practice of putting on sterile gloves and fatigue in utilizing mask. Corroborating with this study, authors presented in their study that the low adherence of nursing students to PPE usage had as factors with most representativeness among undergraduates: physical discomfort (75.8\%) and PPE unavailability or inadequacy in health units (46.6\%). ${ }^{22}$ Students from an international study reported that they often find it difficult to use PPE (21\%) and perform HH (19\%) when busy.

The study presents as limitation the sampling type used in the study, but the periods approached consider undergraduates in laboratory practices, objective of this study.

The manuscript brings important contributions for nursing and public health, related to knowledge and comprehension of the biosafety teaching process in higher education courses in health. The data presented in this study become a great ally in identifying defects in nursing development related to biosafety; in
Biosafety measures in spaces of practices

acknowledging the factors that make the adherence of biosafety measures difficult; in current reflection between the school world and work world, when presenting the need of building an educational process that articulates the professional development with the professional practice needs. ${ }^{16}$

\section{CONCLUSION}

Biosafety measures adopted by nursing undergraduates in daily activities in spaces of laboratory practices are related to the use of Personal Protective Equipment (PPE) and Hand Hygiene $(\mathrm{HH})$. The most used PPE are gloves, white coat and mask, and the moment when the $\mathrm{HH}$ practice is most performed is before and after the laboratory practices, according to students' reports. As regards the scholars' knowledge about biosafety in health, the students summed it up in one word: "prevention".

It is verified that the use of biosafety measures in this environment is still a challenge because according to what was reported the knowledge is broad but limited to PPE and $\mathrm{HH}$ usage. This limitation may be associated with the theme simplification in development of professional nurse, the lack of rigor by professors concerning the biosafety standards in practice places, from laboratory to supervised practice.

\section{REFERENCES}

1. Sousa AFL, Queiroz AAFLN, Oliveira LB, Moura MEB, Batista OMA, Andrade D. Social representations of biosecurity in nursing: occupational health and preventive care. Rev. Bras. Enferm. [Internet]. 2016 Oct [cited 2019 Sep 29]; 69(5):864-871. Available from: http://dx.doi.org/10.1590/0034-7167-2015-0114
2. Santos HPA, Santos MF, Almeida TCA, Dionello AFM, Ferreira LP. A importância da biossegurança no laboratório clínico de biomedicina. Rev Saúde Foco [Internet]. 2019 Jun [citado 2019 Jun 15]; 11(1): 1-16. Available from: http://portal.unisepe.com.br/unifia/wpcontent/uploads/sites/10001/2019/02/017_A- 
IMPORT\%C3\%82NCIA-DA-BIOSSEGURAN\%C3\%87ANO-LABORAT\%C3\%93RIO-CL\%C3\%8DNICO-DE-

BIOMEDICINA.pdf

3. Lima RJV, Tourinho BCMS, Costa DS, Almeida DMPF, Tapety FI, Almeida CAPL, et al. Biological agents and personal and collective protection equipment: knowledge and use among professionals. Rev Pre Infec e Saúde [Internet].2017;3(1):38-48. Available from: https://doi.org/10.26694/repis.v3i3.6684

4. Barbosa ADA, Ferreira AM, Martins ENX, Bezerra AMF, Bezerra JAL. Nurses perception about the use of personal protective equipment in a hospital in parabian. Rev bras educ saúde. [Internet]. 2017 Jun [citado 2019 Jun 15]; 7(1):18. Available from: http://dx.doi.org/10.18378/rebes.v7i1.4858

5. Brasil. Agência Nacional de Vigilância Sanitária. Higienização das mãos em serviços de saúde. Brasília, DF: ANVISA, 2019. Available from: http://portal.anvisa.gov.br/higienizacao-dasmaos

6. Brasil. Ministério do Trabalho e Emprego (BR). Portaria $\mathrm{n}^{\circ} 194$ de 22 de dezembro de 2006. NR6 - Equipamentos de Proteção Individual. Available from:

https: / /www.legisweb.com.br/legislacao/?id=19 6591

7. Brasil. Portaria $N^{\circ} 485$ do Ministério do Trabalho e Emprego, de 11 de novembro de 2005. Aprova a Norma Regulamentadora n. 32 Segurança e saúde no trabalho em estabelecimentos de saúde. Diário Oficial da República Federativa do Brasil, Brasília. 16 nov. 2005. Available from: https://www20.anvisa.gov.br/segurancadopacie nte/index.php/legislacao/item/portaria-n-485de-11-de-novembro-de-2005

8. Lefrève $F$, Lefrève $A M C$, Teixeira JJV. $O$ discurso do sujeito coletivo: uma nova abordagem metodológica em pesquisa qualitativa. Caxias do Sul: EDUCS; 2000.

9. Lefrève AMC, Crestana MF, Cornetta VK. Discourse of the collective subject in the qualitative evaluation of pos-graduation "lato sensu" Courses: Training and Development of Health Manpower - CADRHU, São Paulo - 2002. Saude soc [Internet]. 2003 Jun [citado 2019 Jun 15]; 12(2):68-75. Available from: Rev Pre Infec e Saúde. 2019;5:9309 http: / /dx.doi.org/10.1590/S010412902003000200007

10. Almeida CAPL, Sousa KHJF, Oliveira JLde, Lima LdaS, Santos TS, Amorim FCM et al. Evaluation of a virtual learning environment about educational actions for people with diabetes mellitus. Esc. Anna Nery [Internet]. 2019 Feb [citado 2019 Out 04]; 23(4):1-10. Available from: http://dx.doi.org/10.1590/2177-9465-ean2019-0027

11. Souza EC, Strelciunas ASA, Ferreira LNB, Nascimento KCP. Knowledge about hand hygiene of nursing students. Rev Recien [Internet]. 2017 Jun [citado 2019 Jun 15]; 7(21):41-48. Available from:

https://www.recien.com.br/index.php/Recien/ article/view/241

12. Portoghese I, Leiter MP, Maslach C, Galletta M, Porru F, D'Aloja E, et al. Measuring Burnout Among University Students: Factorial Validity, Invariance, and Latent Profiles of the Italian Version of the Maslach Burnout Inventory Student Survey (MBI-SS). Front Psychol [Internet]. 2018 Nov [citado 2019 Out 04]; 9:2105. Available from: doi:

http://dx.doi.org/10.3389/fpsyg.2018.02105. eCollection 2018

13. Rubbi I, Cremonini V, Artioli G, Lenzini A, Talenti I, Caponnetto V, et al. The public perception of nurses. An Italian cross-sectional study. Acta Biomed Profis Saúde [Internet]. 2017 Jun [citado 2019 Jun 15]; 88(5):31-38. Available from: http://dx.doi.org/10.23750/abm.v88i5S.6884

14. Dias JA, Silva PE, Alves SRP, Souto CGV. Nursing students of knowledge about the equipment personal protection (PPE) used in emergency unit and emergency hospital. Rev Ciênc Saúde Nova Esperança [Internet]. 2016 Jun [citado 2019 Jun 15]; 14(1):4-14. Available from: http://www.facene.com.br/wpcontent/uploads/2010/11/1. -Conhecimento-deacad\%C3\%AAmicos-de-enfermagem_PRONTO.pdf 15. Goje M, Balami AD, Jarma M, Dauda S. Knowledge, attitude, self-efficacy and practice of standard precaution measures by nursing and midwifery students in Damaturu, North-Eastern Nigeria. Int. J. Adv. Community Med [Internet]. 2018 Jan [citado 2019 Out 04]; 1(2):41-46. 
Available

from:

http://www.comedjournal.com/archives/2018.v

1.i2.a.18

16. Parentes KF, Moreira ICC, Melo JKN, Araújo ETH, Costa AP, Veras KCBB. Medidas de precauções padrão adotadas pelos estudantes de enfermagem. Rev Interdiscip [Internet]. 2018 Jun [citado 2019 Jun 15]; 10(4):82-88. Available from: https: / / revistainterdisciplinar.uninovafapi.edu.b r/index.php/revinter/article/view/1336

17. Haque M, Sartelli M, McKimm J, Bakar MA. Health care-associated infections - an overview. Infect Drug Resist [Internet]. 2018 Nov [citado 2019 Out 04]; 11:2321-2333. Available from: http://dx.doi.org/10.2147/IDR.S177247

18. Carter EJ, Mancino D, Hessels AJ, Kelly AM, Larsona EL. Reported hours of infection education received positively associated with student nurses' ability to comply with infection prevention practices: Results from a nationwide survey. Nurse Educ Today [Internet]. 2017 Jun [citado 2019 Jun 15]; 53:19-35. Available from: http://dx.doi.org/10.1016/j.nedt.2017.02.021

19. Petersa A, Borzykowskia T, Tartaria E, Kilpatrickb C, Maib SHC, Allegranzib B, et al. 'Clean care for all - it's in your hands': the 5th May 2019 World Health Organization SAVE LIVES: Clean Your Hands campaign. Antimicrob Resist Infect Control [Internet]. 2019 Apr [citado 2019
Out 04]; 8:1-10. Available from: http://dx.doi.org/10.1186/s13756-019-0513-7

20. Vasconcelos RO, Alves DCl, Fernandes LM, Oliveira JLC. Adhesion to hand hygiene by nursing team in intensive care unit. Enferm Global [Internet]. 2018 Jun [citado 2019 Jun 15]; 17(2):430-476. Available from: http://dx.doi.org/10.6018/eglobal.17.2.284131

21. Presado MHCV, Colaço S, Rafael H, Baixinho CL, Félix I, Saraiva C et al. Learning with High Fidelity Simulation. Ciênc. saúde coletiva [Internet]. 2018 Jan [cited 2019 Oct 05]; 23(1):51 59. Available from: http://dx.doi.org/10.1590/1413-

81232018231.23072017

22. Figueredo VA, Nova BGV, Silva MRC, Firmo WCA, Santos DO. Knowledge about biosafety of concluding students of the health area of a private higher education institution in the city of Bacabal-MA. Interfacehs [Internet]. 2018 Jun [citado 2019 Jun 15]; 13(2):1-12. Available from: http://www3.sp.senac.br/hotsites/blogs/Interfa cEHS/wp-

content/uploads/2019/02/235_InterfacEHS_Artig oRevisado.pdf

Submitted: 2019-08-24

Accept: 2019-10-05

Published: 2019-12-15

\section{COLLABORATIONS}

IPR, ECO, JSSS and HEFC: substantial contributions in work conception or design; in data collecting, analysis and interpretation; in article writing or its critical review; and in the final version to be published. All the authors agree and take the responsibility for the content of this manuscript version to be published.

\section{ACKNOWLEDGMENTS}

Does not apply.

AVAILABILITY OF DATA

Does not apply.

\section{FUDING SOURCE}

Does not apply.

\section{CONFLICTS OF INTEREST}

There are no conflicts of interest to declare. 
Ribeiro IP, et al.

Biosafety measures in spaces of practices

\section{CORRESPONDENCE}

Ivonizete Pires Ribeiro

Address: Rua Vitorino Orthiges Fernandes, 6123 - Uruguai, Teresina - PI, 64073-505, Brazil

Telephone: +55 (86) 2106-0700

E-mail: ivonizeteribeiro@gmail.com 